\title{
Effect of parlour relocation on behaviour and post-adaptation milkability of lactating dairy cows
}

\author{
A Fahim ${ }^{1}$, ML Kamboj' ${ }^{2}$ M Bhakat ${ }^{2}$, TK Mohanty $^{2}$, AS Sirohi $^{3}$ and S Prasad $^{4}$
}

Received: 02 October 2021 / Accepted: 01 November 2021 / Published online: 22 December 2021

(C) Indian Dairy Association (India) 2021

\begin{abstract}
The aim of study was to investigate the effect of parlour relocation on behaviour of lactating cows and to understand the effect of behaviour on post-adaptation milkability in dairy cows. Seventy-two crossbred cows initially milked in tandem milking parlour were relocated to herringbone parlour and observed for 45 milking sessions. Recording of behaviour was done for the individual animal as they entered the holding area till exit after completion of milking. The results showed that there was marked behavioural changes associated with the relocation of animals. Sharp decline in milk yield was observed on the day of relocation which improved in subsequent milking sessions. The mean cortisol level pre and post milking was significantly $(\mathrm{P}<0.01)$ high in novel parlour to which the animals were unfamiliar. The behaviour of animals post-adaptation in holding area and milking area was found to be significantly $(\mathrm{P}<0.01)$ associated with the milkablity traits in terms of milk yield and milk flow. The temperament score of cows significantly $(\mathrm{P}<0.01)$ affected their milk yield and milk flow characteristics. No definite trend was seen due to effect of elimination behaviour on
\end{abstract}

${ }^{1}$ Department of LPM, SVPUAT, Meerut

${ }^{2}$ ICAR-National Dairy Research Institute, Karnal-132001, Haryana ${ }^{3}$ ICAR-CIRC, Meerut Cantt,

${ }^{4}$ ICAR H.Q., New Delhi

Ahmad Fahim ( $\square)$

Department of LPM, COVAS

SVPUAT, Meerut

E-mail: ahmadfahim300@gmail.com milkability. The study concluded that although lactating dairy cows have tendency to adapt in a new system, shifting them in the midst of lactation may cause production losses. The cow behaviour post-adaptation in milking parlours having batch milking may serve as potent tool to select and split large herds, based on milk yield and milk flow rates.

Keywords: Cow behaviour, Dairy cow, Milk yield, Milkability

\section{Introduction}

Good design and facilities are required in animal units to take advantage of natural behaviour which facilitate easy movement of animals and reduce the number of negative interactions with the stock handlers. In general, a quiet and consistent handling helps in promoting better productivity and good animal welfare by reducing the level of fear and stress in animals (Grandin 2018; Coleman and Hemsworth 2014). On a well organized farm, the dairy cows are habituated to milking routine operations. However, they may be often exposed to number of situations on day to day basis, which may be either disturbing their routine or creating a transient stress in them (Breuer et al. 2000; Neisen et al. 2009; Sutherland and Huddart 2012). As a consequence, dairy cows are likely to show behavioral and physiological responses to these multiple stressors (Van Reenen et al. 2002; Eicher et al. 2007).

Milking of cows in an unfamiliar parlour or changing the parlour type and design for better milking, the animals undergo initial stress and has been implicated as one of the major aversions for relocated cows (Grandin 1998). Studies show that relocated cows are subjected to strange surroundings, noise, odours, stock and people which contribute to stress and potential performance losses (Keeling et al. 2002; Grandin 2003; Macuhova et al. 2008; Sutherland et al. 2012). Such situations are characterized by frequent vocalization, defecation, and urination incidences considered as indicators of fear or stress in cattle (de Passillé et al. 1995; Grandin 1998); and increased movement (stepping and kicking) considered as a sign of agitation (Grandin 1993). Soch et al. (1997) recorded production losses with a decrease in milk yield from $19.0 \mathrm{~kg}$ to $10.2 \mathrm{~kg}$ on the first day of milking after moving from stanchion-stall to free-stall housing. Bruckmaier et 
al. (1993) mentioned inhibition of milk letdown in dairy cows milked in an unfamiliar or novel environment. On the other hand, there are studies on cow behavior post-adaptation in milking area in conjunction to holding area that may possibly explain the variation in individual milkablity of cows (Gergovska et al. 2012; Ishiwata et al. 2005) to make important managemental decisions on large farms. In this attempt, the present work was aimed to study the effect of parlour relocation on behaviour of crossbred dairy cows and to understand the milkability of cows in relation to behavior in milking and holding area.

\section{Materials and Methods}

\section{Animals and management}

The study was conducted at the Livestock Research Center, ICAR-National Dairy Research Institute (NDRI), Karnal, Haryana, India. Sixty lactating crossbred Karan Fries (HF X Tharparker) and twelve Karan Swiss (Brown Swiss $\times$ Sahiwal) cows in lactation 1 to 4 were taken for 45 milking sessions. The animals were kept under loose housing system and were monitored through an automatic animal identification system consisting of a neck transponder, portal identification antenna, system controller, and ALPRO Windows kit (DeLaval, ALPRO windows 6.90). Milking was done thrice daily, in morning $05-00$ to $07-00 \mathrm{~h}$, in afternoon $12-30$ to $13-30 \mathrm{~h}$ and in evening 17-30 to $18-30 \mathrm{~h}$. The cows were initially milked in tandem milking parlour post-calving and then relocated to herringbone milking parlour (Average number of days in milk 110.59; range 62 to 175 days). The tandem milking parlour $(2 \times 6)$ provided optimal space conditions for each individual animal, where the cow could stand on milking platform in a box measuring $2.50 \mathrm{~m}$ in length and $0.75 \mathrm{~m}$ in width during milking, unaffected from other animals. The herringbone milking parlour $(2 \times 8)$ had GI pipe frame that provided standing space for milking of 8 cows simultaneously in a row having inner space of $0.75 \mathrm{~m}$, outer space of $1.50 \mathrm{~m}$ and total length of $10.6 \mathrm{~m}$ for batch milking. In both cases, the animals were taken to a holding area adjacent to the milking parlour. The time each cow spent in the holding area before milking varied from $10 \mathrm{~min}$ to $30 \mathrm{~min}$. Once the cows were in the milking parlour the routine was pre-milking udder washing, fore-stripping, cluster attachment, and postmilking teat spray.

\section{Recording of behaviour}

Animal behaviour was monitored daily from the time animal entered the holding area till its exit after completion of milking. Video-recording was done by the help of IR network camera (Model:DS-2CD2032-I). The camera was enabled with infrared technology for true day and night vision. The image capturing was at 15 frames per second (FPS) @ 2048X1536 resolution. In the holding area, behavioral features which were observed were their orientation, movement, licking fellow animals and looking up. In the milking area, FSK response, temperament score of cows and elimination behaviour was recorded. The FSK response was recorded based on flinch, step, and/or kick (FSK) score on 4 point scale (Sutherland and Tops 2014) :1 = no hind foot movement, cow may flinch, shiver or do nothing at all; $2=$ hind leg lifted no higher than $20 \mathrm{~cm}$, step or shuffle of a hind leg; $3=$ hind leg lifted higher than $20 \mathrm{~cm}$, step or forward kick of a hindleg; 4 = backward kick of hind leg. The temperament score was assessed using 5-point scale (as proposed by Tulloh 1961). Other behavior were recorded based on their frequency of occurrence using time-sampling method at 5 min interval during six intermittent morning milking sessions.

\section{Estimation of plasma cortisol level}

Blood collection was done in eight animals before relocation, in tandem parlour before and after milking during morning milking session. The same animals were again selected for blood collection after relocation in herringbone (novel) parlour at day $0,5,10$ and 15 days, pre and post milking during morning milking session. Samples were drawn in sterile heparinized vacutainer tubes from jugular vein puncture, posing minimum disturbance to the animal during collection. The samples were centrifuged at $3000 \mathrm{rpm}$ for $20 \mathrm{~min}$ at $4{ }^{\circ} \mathrm{C}$ to separate the plasma. The plasma was aspirated and stored at $-20{ }^{\circ} \mathrm{C}$ temperature until analysis. Plasma samples were analyzed for cortisol concentrations using commercially available enzyme immunoassay kit (Cortisol EIA kit Item No. 500360, Cayman Chemical Company, Ann Arbor, MI).

\section{Statitistical analysis}

All data were tested for constant variance and departures from normal distribution using the univariate procedure in SAS (SAS Inst., Inc., Cary, NC) and data lacking normality were transformed prior to analysis. Quasi-experimental design technique was used to compare the groups. Parameters with two groups were tested for significant difference in means using student t-test. The parameters having more than two groups were tested for significance using ANOVA. The correlations between cow behaviour at the time of milking and milkability traits were studied using the Spearman's rank correlation coefficient.

\section{Results and Discussion}

\section{Relocation of cows to novel parlour:}

There was marked increase in flinching, stepping and kicking behaviour (FSK response) on the day of introduction at day 0 (Figure 1). FSK response reduced on next day of milking which further reduced and seen in $25 \%$ cows at $30^{\text {th }}$ day of relocation. The novel parlour (Herrinbone type) was associated with greater degree of FSK than the tandem parlour. Similarly, relocation of cows to novel parlour also led to more elimination behavior during milking on the day of introduction. This behaviour was significantly reduced on $3^{\text {rd }}$ day and onward in these cows. There was greater vocalization in cows on the day of introduction which 
Fig. 1 Behavioural pattern in dairy cows relocated to novel parlour

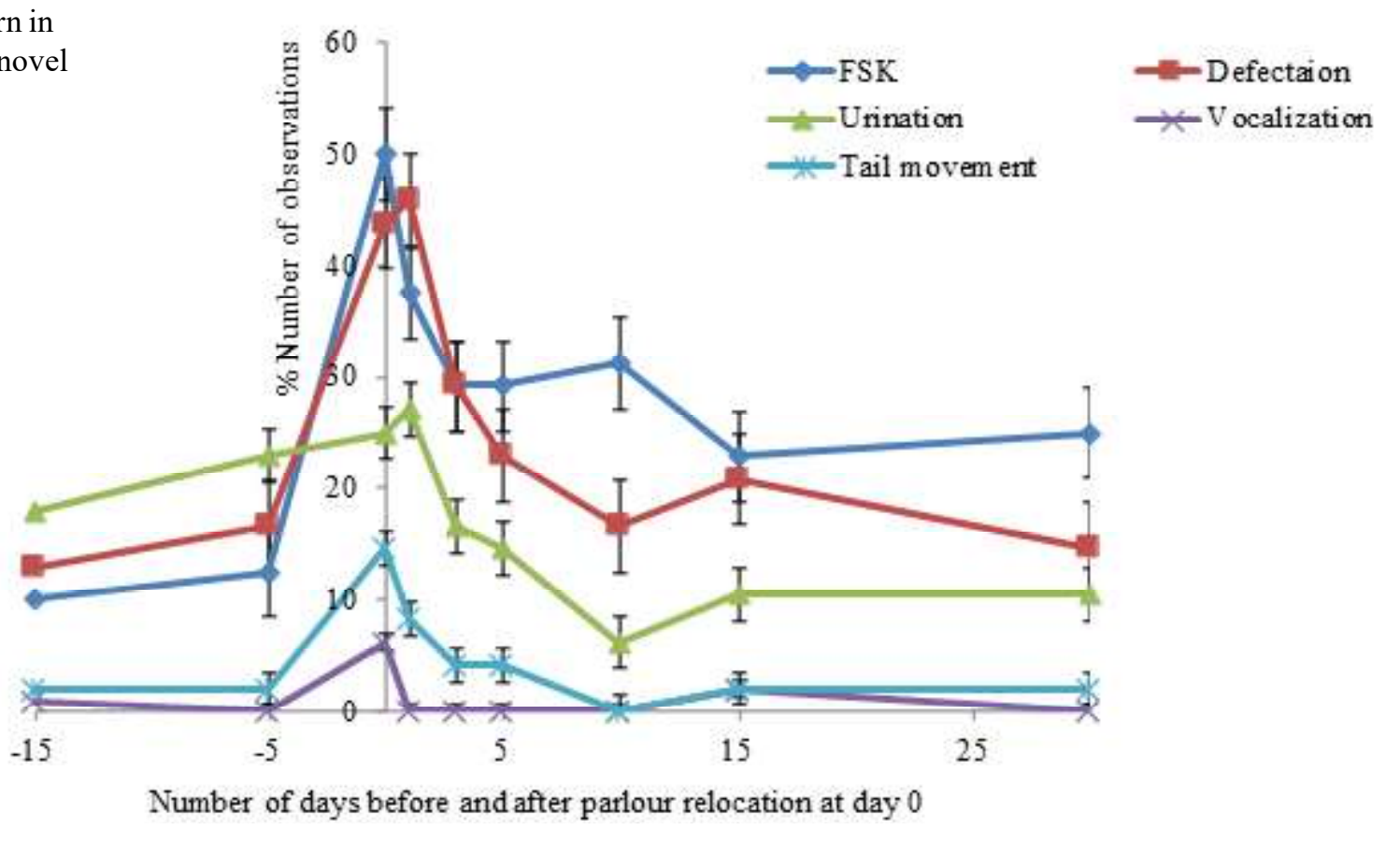

Fig. 2. Daily milk yield in cows relocated to novel palour

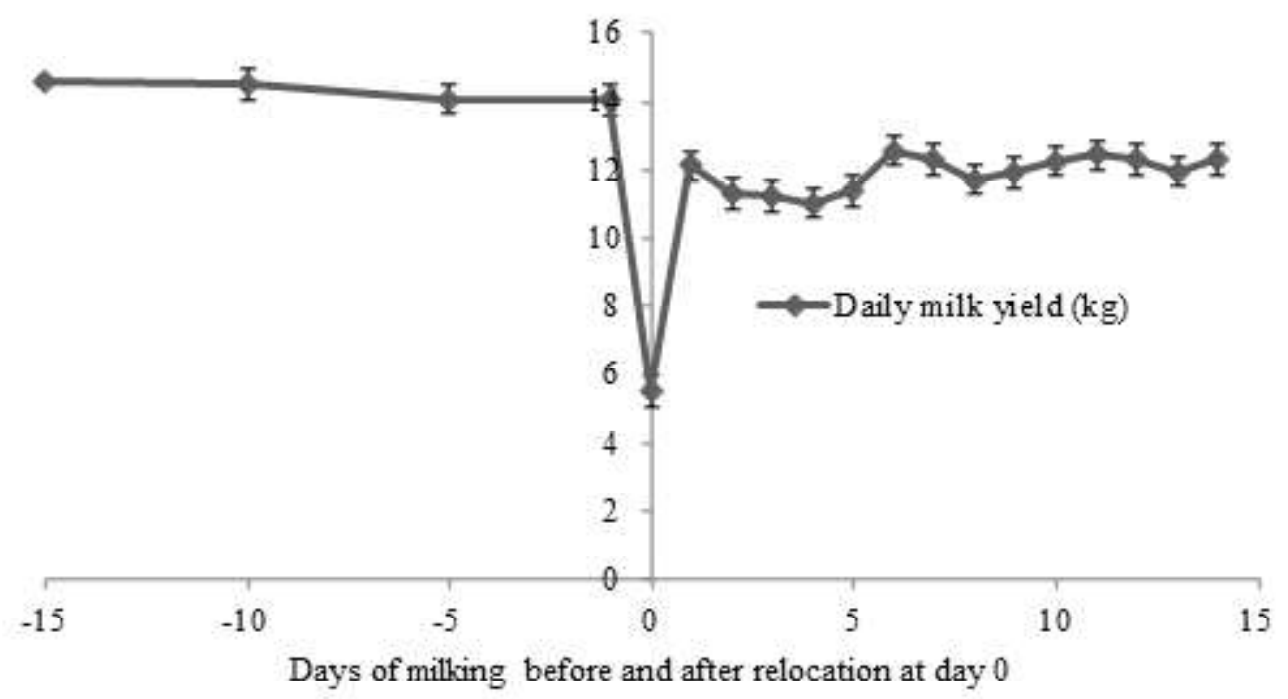

later reduced in subsequent milkings. Earlier studies on change in milking parlour environment or type of parlour suggest varying levels of discomfort and stress response in animals (Hopster et al. 2002; Wenzel et al. 2003; Gygax et al. 2008). Jacobs and Seigford (2012) reported changes in behaviour in dairy cows on day 0 of introduction in a novel parlour with a greater elimination and vocalization response and lowering of milk yield. However, the initial stress and discomfort with the milking process in the new system on $\mathrm{d} 0$ subsequently subsided and the cows appeared to adapt within only a period of $24 \mathrm{~h}$. Rushen et al. (1999) also reported increased incidences of defecation, urination, and vocalization in dairy cows in unfamiliar surroundings.
There was decrease in milk yield after being subjected to novel milking environment (Fig. 2) indicating acute stress in animals. The milk production in crossbred cows initially milked in separate milking boxes was $14.31 \pm 0.61 \mathrm{~kg}$, which showed sharp decline on the day of introduction $(5.51 \pm 0.5 \mathrm{~kg})$. This may be due to social stress in herringbone parlour occurring from lesser individual space, with multiple cows milked simultaneously and adjacent to each other during milking. However, subsequent milking sessions showed improvement in milk yield but with variable yield. The milk yield was not stable up to $10^{\text {th }}$ day of milking which later stabilized, however, the animals did not reach the same potential with which they produced earlier. Jacob and Seigford (2012) reported discrepancy in adaptation time may be due to differences 
Fig. 3 Plasma cortisol concentration $(\mathrm{ng} / \mathrm{ml})$ in dairy cows before and after relocation

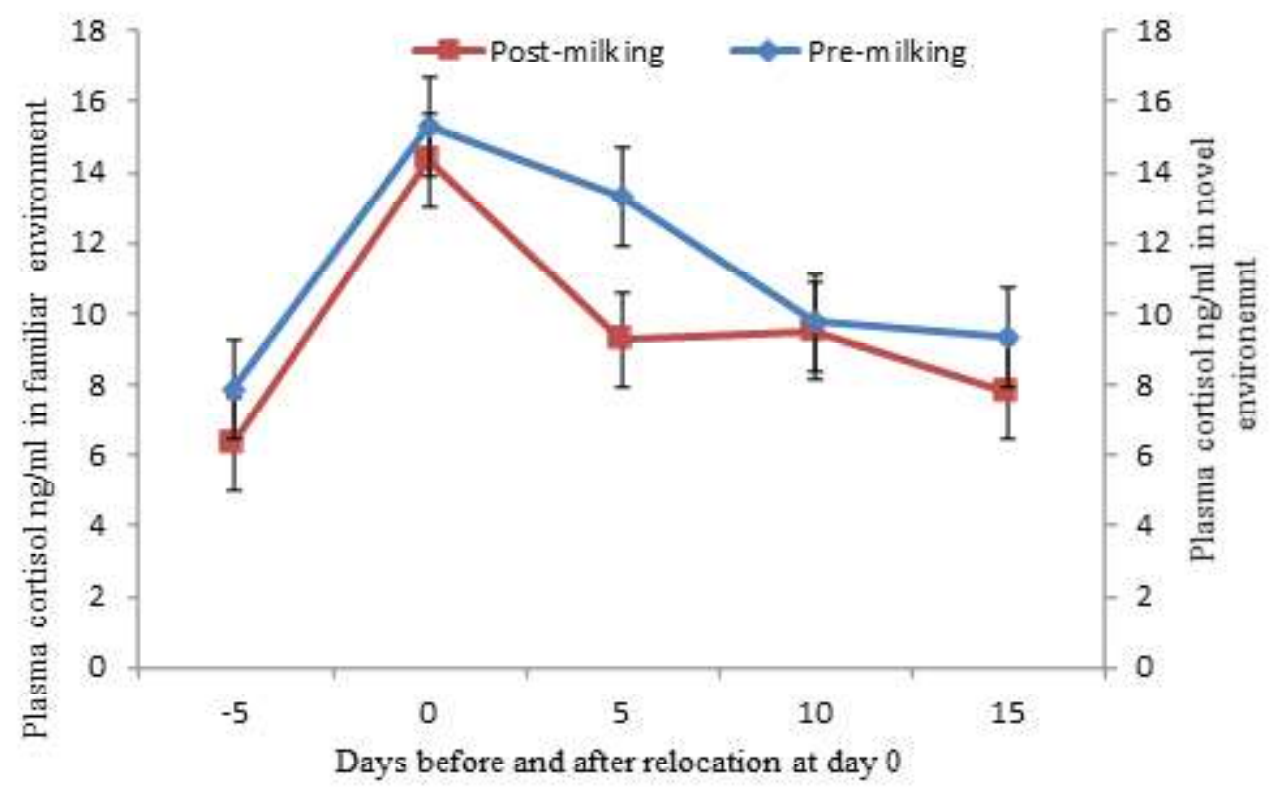

in milk production, milking frequency, milking environment and equipments used for milking. In the present study, the cows were seen to adapt quickly in the new system in less than 5 days, however, to achieve a stabilized production, at least 10 days time was taken. Further, since the animals were shifted in the midst of their lactation, it was found that such shifting of animals could affect their production. It may therefore be suggested from the study to get the animals acquainted for any changes made in milking environment before the lactation commences.

\section{Measurement of cow stress (Cortisol estimation)}

The mean level of cortisol in crossbred dairy cows are presented in Figure 3. The cortisol concentrations pre and post-milking in familiar milking environment differ significantly $(\mathrm{P}<0.01)$. When the cows were relocated to a novel milking environment (herringbone type), there was two fold increase in cortisol level pre-milking which was similar as post-milking. Later, as the cows were habituated, the level of cortisol reduced. The pre-milking and post-milking level of cortisol suggest reduced stress after milk removal. When the cows were brought in novel parlour, they suffered psychological stress which continued even after milking. Jacobs and Seigford (2012) reported similar findings in Holstein dairy cows subjected to automatic milking system from conventional parlours. Bruckmaier et al. (1993) reported cortisol level increase before milking was larger in novel environment than in the familiar environment, indicating the level of stress in cows. Sutherland et al. (2012) reported that in the familiar milking environment, serum cortisol concentrations were lower $(\mathrm{P}<0.05)$ in cows post-milking as compared to pre-milking values, but did not differ $(\mathrm{P}>0.05)$ pre- and post-milking in the novel environment regardless of cow temperament. Furthermore, they also classified the cows as high and low responders (based on their exit times from the crush) and found that cortisol concentrations prior to milking were higher $(\mathrm{P}<0.05)$ in high responders (exit time less than $2 \mathrm{~s}$ ) than low responders (exit time of more than $4 \mathrm{~s}$ ) cows in both the familiar and novel environments. Therefore, in our study it may be suggested that lactating dairy cows adapt quickly to being milked in a new system. Increased concentration of cortisol may be responsible for lower oxytocin levels in cows milked in unfamiliar environment, leading to poor milk letdown (Macuhova et al. 2002; Weiss et al. 2004; Sutherland et al. 2012). This may be the reason for decline in milk yield in unfamiliar milking environment in our study.

\section{Effect of behaviour on milkability of cows post-adaptation}

The milk yield ( $\mathrm{kg} /$ day) in cows which oriented towards the milking area was significantly $(\mathrm{P}<0.01)$ higher than those which oriented sideways and opposite to milking (Table 1). Likewise, the single session milk yield (morning) was also higher $(\mathrm{P}<0.01)$ for these animals. The cows having such tendency had significantly $(\mathrm{P}<0.01)$ high average and peak flow rates $(1.10 \pm 0.01$ and $2.21 \pm 0.02 \mathrm{~kg} / \mathrm{min}$ ) during milking. There was positive and significant correlation for milkability traits in crossbred cows based on their preference for orientation (Table 2). Similarly, the movement of cows in parlour for milking was also associated with higher milk yield $(14.01 \pm 0.15 \mathrm{~kg})$ and positive correlation $(\mathrm{r}=$ $0.528, \mathrm{P}<0.01)$, with significantly higher average and peak flow rate $(1.16 \pm 0.01$ and $2.34 \pm 0.03 \mathrm{~kg} / \mathrm{min})(\mathrm{r}=0.428$ and $0.422 ; \mathrm{P}<0.01)$. Kumar et al. (2019) studied pattern of movement in Jersey crossbred cows and reported significant $(\mathrm{P}<0.01)$ variation in milk yield, milking time and milk flow rate based on exit score and parlour leaving speed (PLS). Gergovska et al. (2012) reported that for an efficient milking operation one should invest less time on the individual animal. In an another study, Suzuki et al. (1982) observed the movement of individual cows in the holding area 
Table 1 Effect of cow behavior in holding and milking area on milkability (Mean \pm SE)

\begin{tabular}{|c|c|c|c|c|c|c|c|}
\hline Parameter & Observations & $\begin{array}{l}\text { No. of } \\
\text { observations } \\
(\%)\end{array}$ & $\begin{array}{l}\text { Total daily } \\
\text { milk yield } \\
(\mathrm{kg})\end{array}$ & $\begin{array}{l}\text { Milk } \\
\text { yield/session } \\
(\mathrm{kg})\end{array}$ & $\begin{array}{l}\text { Machine-on } \\
\text { time } \\
(\mathrm{min})\end{array}$ & $\begin{array}{l}\text { Average } \\
\text { milk flow } \\
(\mathrm{kg} / \mathrm{min})\end{array}$ & $\begin{array}{l}\text { Peak milk } \\
\text { flow } \\
(\mathrm{kg} / \mathrm{min})\end{array}$ \\
\hline \multicolumn{8}{|l|}{ Holding area } \\
\hline & Sideways & 22.1 & $11.95^{\mathrm{B}} \pm 0.17$ & $5.30^{\mathrm{B}} \pm 0.15$ & $5.06^{\mathrm{B}} \pm 0.07$ & $1.05^{\mathrm{B}} \pm 0.01$ & $2.11^{\mathrm{B}} \pm 0.03$ \\
\hline & Opposite & 29.8 & $11.89^{\mathrm{B}} \pm 0.16$ & $5.12^{\mathrm{B}} \pm 0.14$ & $5.03^{\mathrm{B}} \pm 0.06$ & $1.03^{\mathrm{B}} \pm 0.01$ & $2.08^{\mathrm{B}} \pm 0.03$ \\
\hline \multirow[t]{2}{*}{ Licking } & Present & 18.4 & $11.02^{\mathrm{A}} \pm 0.17$ & $4.57^{\mathrm{A}} \pm 0.15$ & $4.69^{\mathrm{A}} \pm 0.07$ & $0.98^{\mathrm{A}} \pm 0.01$ & $1.99^{\mathrm{A}} \pm 0.03$ \\
\hline & Absent & 81.6 & $13.65^{\mathrm{B}} \pm 0.11$ & $6.46^{\mathrm{B}} \pm 0.10$ & $5.75^{\mathrm{B}} \pm 0.05$ & $1.13^{\mathrm{B}} \pm 0.01$ & $2.28^{\mathrm{B}} \pm 0.02$ \\
\hline \multirow[t]{2}{*}{ Looking up } & Seen & 42.0 & $11.82^{\mathrm{A}} \pm 0.14$ & $5.13^{\mathrm{A}} \pm 0.12$ & $5.01^{\mathrm{A}} \pm 0.06$ & $1.03^{\mathrm{A}} \pm 0.01$ & $2.09^{\mathrm{A}} \pm 0.02$ \\
\hline & Not seen & 58.0 & $12.85^{\mathrm{B}} \pm 0.13$ & $5.90^{\mathrm{B}} \pm 0.12$ & $5.42^{\mathrm{B}} \pm 0.05$ & $1.08^{\mathrm{B}} \pm 0.01$ & $2.18^{\mathrm{B}} \pm 0.02$ \\
\hline \multicolumn{8}{|l|}{ Milking area } \\
\hline & Nervous & 6.3 & $11.41^{\mathrm{D}} \pm 0.26$ & $5.10^{\mathrm{D}} \pm 0.23$ & $5.32^{\mathrm{B}} \pm 0.10$ & $0.98^{\mathrm{D}} \pm 0.02$ & $1.97^{\mathrm{D}} \pm 0.04$ \\
\hline \multirow{4}{*}{$\begin{array}{l}\text { Elimination } \\
\text { behaviour }\end{array}$} & Defecation & 11.7 & $12.60^{\mathrm{bc}} \pm 0.20$ & $5.73^{b} \pm 0.18$ & $5.32^{b} \pm 0.08$ & $1.06^{\mathrm{ab}} \pm 0.02$ & $2.15^{\mathrm{ab}} \pm 0.03$ \\
\hline & Urination & 6.4 & $12.16^{\mathrm{a}} \pm 0.26$ & $5.36^{a} \pm 0.23$ & $5.14^{\mathrm{a}} \pm 0.10$ & $1.05^{\mathrm{a}} \pm 0.02$ & $2.12^{\mathrm{a}} \pm 0.04$ \\
\hline & Both & 7.6 & $12.55^{\mathrm{c}} \pm 0.24$ & $5.78^{b} \pm 0.21$ & $5.30^{\mathrm{b}} \pm 0.10$ & $1.08^{\mathrm{b}} \pm 0.02$ & $2.19^{b} \pm 0.04$ \\
\hline & None & 74.3 & $12.04^{\mathrm{ab}} \pm 0.11$ & $5.19^{\mathrm{a}} \pm 0.10$ & $5.10^{\mathrm{a}} \pm 0.04$ & $1.03^{\mathrm{a}} \pm 0.01$ & $2.08^{\mathrm{a}} \pm 0.02$ \\
\hline
\end{tabular}

Values with different superscript in upper case letters in column differ significantly at $\mathrm{P}<0.01 \&$ in lower case letter at $\mathrm{P}<0.05$

Table 2 Rank correlation between cow behavior at milking and milkability

\begin{tabular}{llllll}
\hline Parameters & $\begin{array}{l}\text { Total daily } \\
\text { milk yield }\end{array}$ & $\begin{array}{l}\text { Milk yield/ } \\
\text { Session }\end{array}$ & $\begin{array}{l}\text { Machine-on } \\
\text { time }\end{array}$ & $\begin{array}{l}\text { Average milk } \\
\text { flow }\end{array}$ & $\begin{array}{l}\text { Peak milk } \\
\text { flow }\end{array}$ \\
\hline Orientation & $0.348^{* *}$ & $0.318^{* *}$ & $0.321^{* *}$ & $0.290^{* *}$ & $0.288^{* *}$ \\
Movement & $0.528^{* *}$ & $0.488^{* *}$ & $0.507^{* *}$ & $0.428^{* *}$ & $0.422^{* *}$ \\
Licking & $-0.375^{* *}$ & $-0.340^{* *}$ & $-0.358^{* *}$ & $-0.262^{* *}$ & $-0.262^{* *}$ \\
Looking up & $-0.180^{* *}$ & $-0.172^{* *}$ & $-0.179^{* *}$ & $-0.143^{* *}$ & $-0.142^{* *}$ \\
Temperament score & $-0.143^{* *}$ & $-0.071^{*}$ & -0.012 & $-0.155^{* *}$ & $-0.153^{* *}$ \\
Elimination behaviour & 0.017 & $0.045^{*}$ & $0.053^{*}$ & 0.028 & 0.027 \\
\hline
\end{tabular}

**. Correlation is significant at the 0.01 level (2-tailed).

*. Correlation is significant at the 0.05 level (2-tailed).

with a strong correlation with dominance order, which depends on several factors including their level of production. The effect of cow behaviour on milkability could assess the level of comfort a cow feels during milking, as cows which orient themselves towards the milking area waited for their turn of milking, others trying to escape the situation. Such cows need to be selected for milking in advanced milking parlours, especially where batch milking is done so that milking process is completed comfortably with increased cow comfort and milker comfort.

In the holding area, there were animals which showed licking behavior (18.4\% cows) and looking up behavior ( $42.0 \%$ cows) while waiting for their turn of milking. These behavioural traits in dairy cows were also found to affect their milkability. The cows which were engaged in licking the fellow animals yielded significantly $(\mathrm{P}<0.01)$ lower amount of milk $(11.02 \pm 0.17 \mathrm{~kg})$ with a poor flow rate $(0.98 \pm 0.01 \mathrm{~kg} / \mathrm{min})$. There was significant negative correlation for animals engaged in frequent licking with the milkability traits (Table 2). Similarly, the cows which had tendency to look frequently with their heads raised also had lower yield and milking rate, which was negatively correlated. Ishiwata et al. (2005) in a similar study reported that some cows are cautious about the surrounding environment and might also be fearful of the surrounding environment including humans and other cows (Hemsworth et al. 2000; Munksgaard et al. 2001). This might be the reason for lower yield in such cows exhibiting licking and looking up behavior. The results of present study were in agreement to the reports of Ishiwata et al. (2005) who found that the cows showing more 'looking up' behaviors took longer time 
to enter the milking parlor and had lower milk yields irrespective of lactation period.

The differences in milk yield due to temperament score in dairy cows was highly significant $(\mathrm{P}<0.01)$ (Table 1$)$. A significant negative correlation was found for the temperament score of cows with milkability (Table 2). No definite trend due to elimination behaviour was seen on milkability of cows. The observations were in agreement to Kumar et al. (2019) who reported significantly $(\mathrm{P}<0.01)$ higher milk yield, milking durations and milk flow rate for docile cows compared to nervous cows. Similar findings were reported by Bagnato et al. (2007), Gergovska et al. (2012) and Chauhan et al. (2013). Prasad and Jayalaxmi (2014) reported higher milk yield in docile cows (nearly three times more) compared to nervous cows, which has tendency to hold-up milk in stress situation. Jacobsen et al. (2008) reported that temperament traits have major effect on the time needed for servicing the individual animal and therefore they are extremely important on large farms. The machine-on time due to temperament was more $(\mathrm{P}<0.01)$ in aggressive cows due to difficult handling and more of milking irregularities, like cluster slips and reattachments. The aggressive cows had significantly $(\mathrm{P}<0.01)$ lower average and peak flow rate, which prolonged the machine-on time and also reduced the milk yield. The higher temperament score of dairy cows in such parlours may be due to uneasiness of being milked in batches, non-adjustment in making group entry inside the milking area i.e. on milking platform or unfavourable milking side of double row parlour. Chauhan et al. (2013) also reported higher milk yield in docile cows under similar environment in comparison to aggressive cows due to more let down time and difficult handling. Urination and defecation are frequently observed in milking parlours. The pattern of defecation and urination is also quite variable, as any kind of stress may stimulate this behaviour (Kulinova et al. 2012). In the present study, it has been tried to know the effect of occurrence of this particular behaviour on various milkability traits. Robichaud et al. (2011) reported that frequency of defecation and urination were not correlated with parity, milk production, body weight, days in milk or dry matter intake in dairy cows. Aland et al. (2002) found that most defecation occurred during the hours when the animals were most active; that is, during milking and feeding. Therefore, it is quite necessary to have a better understanding of this behaviour in dairy cows so that milkability and milk quality are not affected by this behaviour and better management practices could be developed to maintain hygiene in the milking parlour. In a report, it was mentioned that buffaloes before they enter the antechamber of the milking parlor, should be washed to stimulate defecation and urination, and eliminate horn flies. It also promotes body cleanliness, thermal comfort and reduces stress (de Gusmao Couto 2016).

\section{Conclusions}

The results revealed that relocating parlour in lactating cows may cause stress in animals with a sharp decline in their milk yield. The animals although have tendency to adapt in a new system, shifting them in the midst of lactation may cause production losses and previous production levels could not be attained by the shifted cows. It may therefore be suggested that any such change made at a livestock farm should get the animals acquainted before the lactation commences which could possibly minimize their production losses. The cow behaviour postadaptaion in milking parlours (herringbone type) may serve as potent tool to select and split large herd suitable for batch milking based on milk yield and milk flow rates.

\section{Acknowledgments}

The authors express sincere thanks to the Director, NDRI, Karnal, for providing necessary facilities and funding for carrying out the research work.

\section{References}

Aland A, Lidfors L, Ekesbo I (2002) Diurnal distribution of dairy cow defecation and urination. Appl Anim Behav Sci 78: 43-54

Bagnato A, Rossoni A, Nicoletti C, Jakobsen J, Santus E (2007) Milkability and temperament mace correlation and pilot study in dairy cattle populations. Interbull Bull 37: 95-97.

Breuer K, Hemsworth PH, Barnett JL, Matthews LR, Coleman GJ (2000) Behavioural response to humans and the productivity of commercial dairy cows. Appl Anim Behav Sci 66: 273-88

Bruckmaier RM, Schams D, Blum JW (1993) Milk removal in familiar and unfamiliar surroundings: concentrations of oxytocin, prolactin, cortisol and beta-endorphin. J Dairy Res 60: 449-56

Chauhan HD, Patel HA, Ankuya KJ (2013) Effect of dairy temperament on milkability of lactating Kankrej cows. Wayamba J Anim Sci 5: 554-57

Coleman GJ, Hemsworth PH (2014) Training to improve stockperson beliefs and behaviour towards livestock enhances welfare and productivity. Rev Sci Tech 33: 131-37.

De Gusmao Couto A (2016) Ethology: A Study of Buffalo Behavior Aiming at Milk Yield. http://home.valornet.com/pcwdb.

De Passille AM, Rushen J, Martin F (1995) Interpreting the behavior of calves in an open-field test: A factor analysis. Appl Anim Behav Sci 45: $201-13$

Eicher SD, Schutz M, Kearney F, Willard S, Bowers S, Gandy S, Graves K (2007) Prepartum milking effects on parlour behaviour, endocrine and immune responses in Holstein heifers. J Dairy Res 74: 417-24

Gergovska Z, Miteva T, Angelova T, Yordanova D, Mitev J (2012) Relation of milking temperament and milk yield in Holstein and Brown Swiss cows. Bulg J Agric Sci 18: 771-77

Grandin T (1993) The effect of previous experiences on livestock behaviour during handling. Agri-Practice 14: 15-20

Grandin T (1998) Handling methods and facilities to reduce stress in cattle. Vet Clinics North Am: Food Anim Prac 14: 325-41

Grandin T (2003) Transferring results of behavioral research to industry to improve animal welfare on the farm, ranch and the slaughter plant. Appl Anim Behav Sci 81: 215-228 
Grandin T (2018) Welfare problems in Cattle, Pigs, and Sheep that persist even though Scientific research clearly shows how to prevent them. Anim 8: 124

Gygax L, Neuffer I, Kaufmann C, Hauser R, Wechsler B (2008) Restlessness behaviour, heart rate and heart rate variability of dairy cows milked in two types of automatic milking systems and auto-tandem milking parlours. Appl Anim Behav Sci 109: 16779

Hemsworth PH, Coleman G, Barnett JL, Borg S (2000) Relationships between human-animal interactions and productivity of commercial dairy cows. J Anim Sci 78: 2821-2831

Hopster H, Bruckmaier RM, Van der Werf JTN, Korte SM, Macuhova J, Korte-Bouws G (2002) Stress responses during milking: Comparing conventional and automatic milking in primiparous dairy cows. $\mathrm{J}$ Dairy Sci 85: 3206-3216

Ishiwata T, Uetake K, Kilgour RJ, Tanaka T (2005) Looking up behaviour in the holding area of the milking parlour: its relationship with stepkick, flight responses and productivity of commercial dairy cows. Anim Sci J 76: 587-93.

Jacobs JA, Siegford JM (2012) Lactating dairy cows adapt quickly to being milked by an automatic milking system. J Dairy Sci 95:1575-1584

Jakobsen JH, Palucci V, Jorjani H (2008) Feasibility of international genetic evaluation for workability traits. Interbull Bull 38:101-101

Keeling L, Jensen P (2002) Behavioural Disturbances, Stress and Welfare. In The Ethology of Domestic Animals: An Introductory Text, 1st ed.; Jensen, P., Ed.; CAB International: Wallingford, UK; pp. 79-98

Kulinova K, Maèuhová L, Uhrinèat M, Tanèin V (2012) The effect of stressful treatment before and during milking on milkability of dairy ewes. Vet med zootech 57: 39-43

Kumar A, Mandal DK, Mandal A, Bhakat C, Chatterjee A, Rai S (2019) Effects of Milking Temperament on Milk Yield, Udder Health and Milk Composition in Crossbred Jersey Cows. Int J Livest Res 9: 187-194

Macuhová J, Tancin V, Kraetzl W, Meyer HHD, Bruckmaier RM (2002) Inhibition of oxytocin release during repeated milking in unfamiliar surroundings: the importance of opioids and adrenal cortex sensitivity. J Dairy Res 69: 63-73

Maèuhová L, Uhrinèat M, Brouèek $\mathrm{J}$, Tanèin V (2008) Reaction of primiparous dairy cows reared in early postnatal period in different systems on milking conditions. Slovak J Anim Sci 41: 98-04

Munksgaard L, De Passillé AM, Rushen J, Herskin MS, Kristensen AM (2001) Dairy cows' fear of people: social learning, milk yield and behaviour at milking. Appl Anim Behav Sci 73: 15-26

Neisen G, Wechsler B, Gygax L (2009) Effects of the introduction of single heifers or pairs of heifers into dairy-cow herds on the temporal and spatial associations of heifers and cows. Appl Anim Behav Sci 119: $127-136$

Prasad RMV, Jayalaxmi P (2014) Studies on the temperament of Murrah buffaloes with various udder and teat shapes and its effect on milk yield. Buff Bull 33: 170-176
Robichaud MV, de Passille AM, Pellerin D and Rushen J (2011) When and where do dairy cows defecate and urinate? J Dairy Sci 94: 48894896

Rushen J, De Pasielle AMB, Munksgaard L (1999) Fear of people by cows and effects on milk yield, behavior, and heart rate at milking. J Dairy Sci 82: 720-27

Soch M, Kolarova P, Rehout V, Kosvanec K, Hajic F, Citek J (1997) Effect of dairy cows moving from tie-stall to loose housing system on their production and behaviour. Sbornik ZF JU Ceske BudejoviceZootech Rad. 14: 77-86

Sutherland MA, Tops M (2014) Possible involvement of oxytocin in modulating the stress response in lactating dairy cows. Front in Psych 5: 1-7

Sutherland MA, Rogers AR, Verkerk GA (2012) The effect of temperament and responsiveness towards humans on the behavior, physiology and milk production of multi-parous dairy cows in a familiar and novel milking environment. Physio and Behav 107: 329-337

Sutherland MA, Huddart FJ (2012) The effect of training first-lactation heifers to the milking parlor on the behavioral reactivity to humans and the physiological and behavioral responses to milking and productivity. J Dairy Sci 95: 6983-6993

Suzuki S, Hidari H, Saito Y, Sakaguchi A (1982) The order of entry of cows into a milking parlour and moving in the holding area. Res Bull Obh Univ 12: 317-321

Tulloh NM (1961) Behaviour of cattle in yards. II. A study of temperament. Anim Behav 9: 25-30

Van Reenen CG, Van der Werf JTN, Bruckmaier RM, Hopster H, Engel B, Noordhuizen JPTM (2002) Individual differences in behavioural and physiological responsiveness of primiparous dairy cows to machine milking. J Dairy Sci 85: 2551-2561

Weiss D, Helmreich S, Möstl E, Dzidic A, Bruckmaier RM (2004) Coping capacity of dairy cows during the change from conventional to automatic milking. J Animal Sci 82: 563-570

Wenzel C, Schonreiter-Fischer S, Unshelm J (2003) Studies on step-kick behavior and stress of cows during milking in an automatic milking system. Livest Prod Sci 83: 237-246 